CHILD LABOR AND BEHAVIOR ANALYSIS: A CASE STUDYI

\title{
TRABALHO INFANTIL E ANÁLISE DO COMPORTAMENTO: UM ESTUDO DE CASO
}

\author{
SANDy HobBS AND Jim MCKeCHNiE \\ UNIVERSITY OF PAISLEY, SCOTLAND
}

\begin{abstract}
RESUMO
O Grupo de Pesquisa sobre Trabalho Infantil (CERG) da Universidade de Paisley surgiu de uma revisão crítica de dois analistas do comportamento que notaram que, embora o trabalho infantil seja comum em todo o mundo, ele não tem sido objeto de muitos estudos psicológicos. Pesquisas do CERG demonstraram que a norma para jovens na Grã Bretanha é terem trabalho remunerado ainda em idade escolar. Foi também mostrado que trabalhar mais do que dez horas por semana está associado com desempenho escolar fraco. Membros do CERG argumentam que, embora seja compreensível a indignação moral por certas formas de trabalho infantil, esta pode ser contra produtiva se não for acompanhada por uma análise precisa dos problemas e das soluções propostas. CERG argumentou que a pesquisa sobre trabalho infantil pode ser melhor conduzida dentro do escopo de um Modelo Balanceado, que possibilita considerar lado a lado os custos e benefícios existentes.
\end{abstract}

Palavras-chave: trabalho infantil, análise comportamental, crianças

\begin{abstract}
The work of the Child Employment Research Group (CERG) at the University of Paisley grew out of a critical review by two behavior analysts who noted that although child labor is common throughout the world, it has not been the subject of much study by psychologists. Research by CERG has demonstrated that it is the norm for young people in Britain to have paid employment while still of school age. Working more than ten hours per week has also been shown to be associated with poor school performance. Members of CERG argue that although moral indignation at certain forms of child labor is understandable, it may be counterproductive if not accompanied by precise analysis of both the problems and the proposed solutions. CERG has argued that research on child labor might be conducted within the scope of a Balance Model which allows for the possibility of cost and benefits existing side by side.
\end{abstract}

Key words: child labor, behavior analysis, children

In the mid-1980s, two behavior analysts began to study child labor. In a conference paper (Hobbs \& Cornwell, 1985) and a journal article (Hobbs \& Cornwell, 1986) they drew attention to a number of facts. First, it is common for children to work throughout the world, "work" being used to mean engagement in economic activity. Second, most of the scholarly literature on children's work is written by sociologists and social anthropologists. Third, these writers frequently suggest that some forms of child labor may be psychologically damaging. However, fourth, psychologists, including behavior analysts, have paid little attention to this important aspect of childhood. What contingencies had led psychologists to avoid a major area of human behavior? One possibility is that, since developmental psychology is focussed mainly on the children of Western Europe and North America, child labor is overlooked because it is seen as primarily a feature of economically underdeveloped countries. There were a few psychologists who employed the term "work" in discussing child rearing. They referred to circumstances where adults attempted to exercise strict control of children's play as "turning play into work" (see, for example, Lepper \& Greene, 1975). This seemed an unhelpful metaphor, used as a rhetorical device

1 Versions of this paper were presented at the Think Tank on Metacontingencies and Cultural Analysis, Campinas, SP, 22-28 August, 2005, and at XIV

Encontro Brasileiro de Psicoterapia e Medicina Comportamental, Campinas, SP, 25-28 August, 2005. E-mail: hobb-asO@wpmail.paisley.ac.uk 
by writers who extolled the virtues of "intrinsic" over "extrinsic" reinforcement. This reference to children's metaphorical "work" also made it more ironic that psychologists were not considering actual children's "work" as the term is normally employed.

Following this initial step, there gradually emerged the programme of research carried out by the Child Employment Research Group (CERG) at the University of Paisley. Before describing some features of that research, it is necessary to outline some of the limiting factors which shaped the way in which it developed.

First, as already noted, there was no existing body of research by behavior analysts. There is an isolated reference to child labor in Walden Two, where children are said to "work at an early age - moderately but happily" (Skinner, 1948, p 48). Clearly, what Skinner had in mind when envisaging early, moderate and happy work was quite different from the forms of child labor which are most frequently discussed (See, for example, Hobbs, McKechnie \& Lavalette, 1999). This implicitly raised a question important for both scholars and campaigners: Are there both good and bad forms of children's work?

Secondly, although behavior analysis has a distinctive approach to the development of concepts and terminology, a behavior analyst working in this area will of necessity have to collaborate and debate with psychologists who are not behaviorists and with specialists in areas such as sociology, social policy, social anthropology and pediatrics. Skinner (1976/1974, pp 271-272), discussing the language he has employed in About behaviourism, wrote: "...I have freely used the lay vocabulary while accepting the responsibility of providing a technical translation on demand..."

A behavior analyst entering a new field must go beyond Skinner's distinction between "lay" and "technical" terms, and acknowledge that other scholars have their own technical terminology to which they are attached. Behaviorist terminology can appear a threat to them and hence may sometimes impede communication. Much of what has been written by CERG has not used the technical terminology of behaviorism. It is either only implicitly behaviorist in character or at least compatible with behaviorism.

Thirdly, since there was virtually no history of psychological research on child labor in Britain, there was little prospect at first of finding substantial funding for such a programme of research. Indeed, when the research on child labor by CERG began, there was little academic research in any discipline on children's work.

Fourthly, given that resources were limited, it seemed appropriate to begin the research by investigating children's work near to home, in Britain. This had the apparent disadvantage that most scholarship and public debate was focused not on economically advanced countries such as Britain, but on economically less developed countries in Africa, Asia and Latin America. On the other hand, by investigating child employment in Britain it might prove easier to explore both the supposedly positive aspects of children's work and the supposedly negative aspects.

\section{EARLY Findings of CERG}

The first question to be dealt with concerned definition. What is a child? What is 
work? To the United Nations a child is anyone under 18 years of age, but in ordinary usage 15, 16 and 17 year olds are seldom called "children" today, "teenager" and "adolescent" being the more usual terms. British research, including that of CERG, has tended to draw a line at 16 years old, the official minimum school leaving age, because the legal status of workers above and below that age differs. Children of school age theoretically require to have the permission of the local education authority (Cornwell, Graham, \& Hobbs, 1999). Whether that arbitrary line would be justified in terms of the development of the individual is debateable.

"Work" is a highly complex and problematic term, as may be judged by the number of pages devoted to it in the Oxford English Dictionary (see Hobbs \& McKechnie, 1997). Because the CERG team hoped its research would be relevant to some easily identifiable issues of social policy, like other researchers they have concentrated on work as an economic activity, in particular paid employment outside the family. However, problems remain. Some researchers (e.g. Pond \& Searle, 1991) would include in their concept of "work" delivering milk or newspapers and serving in a shop or restaurant but not babysitting, even if it is done for payment. Their argument is that babysitting does not seem to be included in the legislation aimed at restricting child employment. However, since it is predominantly a female activity, to leave it out allows the impression that males work more frequently than females. (If one includes babysitting, levels of employment are generally equivalent, as demonstrated by Hobbs \& McKechnie, 1997).

The discussion so far has referred only to job labels. The same label may cover different activities. For example, a girl employed in a supermarket may operate a checkout till, whilst a boy in the same company may spend most of his time stacking shelves. Most research on child employment, including that of CERG, relies on questionnaires and interviews. From the perspective of behavior analysis, this is not very satisfactory. However, the practical difficulties involved in observing young people at work are substantial, and it is only very recently that CERG has been able to start to do so. Anxieties about the validity of questionnaire responses are not only on matters of principle. The first major study of child labor by psychologists in the United States devoted some time to systematic observation of adolescents at work. Greenberger, Steinberg and Ruggiero (1982) and Steinberg, Greenberger and Ruggiero (1982) found only a very weak relationship between observations and self-report. This inconvenient fact, although published, was seldom mentioned subsequently either by the researchers themselves or other scholars. It suggests that trying to move the study of child employment in a more behavioural direction may be difficult.

The first empirical research by CERG concerned what may be termed the "nature and extent" of child employment in Britain. Some small scale surveys clearly showed that children in Britain typically have experience of paid employment before they reach the legal minimum age for leaving school. Initially claims to this effect by CERG (Lavalette, McKechnie \& Hobbs, 1991) and others (e.g. Pond \& Searle, 1991) were met with disbelief by government ministers. (See Hobbs \& McKechnie, 1997, for details) Their position was that work by children in Britain was rare and largely restricted to delivery jobs. 
Gradually the evidence accumulated became overwhelming and it has now become widely accepted that British children, more often than not, have experience of work (see, for example, Mizen, Bolton \& Pond, 1999). This was only a small victory for evidence over prejudice, but since the prejudices were held by important politicians it was nevertheless a worthwhile achievement.

To establish in broad terms how many British children work and what jobs they do is not in itself a major contribution. However, merely by showing that work is varied and widespread established that there was something there to be studied. Many questions could be asked. At first, the most obvious one was the relationship between work and schooling. One of the aims of legislation on child employment was to ensure that the education of the working child was not harmed. One of the "facts" about child employment in Britain which we helped to establish was that the laws were ineffective, since the majority of children were working illegally (Hobbs \& McKechnie, 1997). The possibility that work was harmful to the education of at least some working children had to be considered.

Over a number of studies, a fairly consistent pattern emerged (McKechnie \& Hobbs, 2001), the robustness of which is suggested by the fact that similar outcomes have emerged from studies in the United States (see Stern \& Briggs, 2001). If one compares the academic performance of school students with jobs with that of students who do not have jobs, there are no significant differences. However, if one takes account of the number of hours per week worked during the school term, significant differences do emerge. Those who work more than ten hours per week tend to perform less well at school than those who work fewer hours. The performance of those who work five hours per week or less tends to be at least as good as, and often better than, those who do not work.

These are correlational studies and we cannot be sure of what key functional relationships lie behind these results. Working long hours may mean that the student is tired and less able to concentrate at school. On the other hand, students who perform poorly at school and hence find schooling an unrewarding experience may be more likely to seek satisfaction in commitment to a job. The fact that those without jobs often do less well than those who work a little may be due to the fact that some students performing poorly at school are discouraged from working lest the job interfere with their studies. In addition, students lacking the skills required to succeed at school may also lack the skills to obtain and hold down a job. Whatever the explanations, the link between hours worked and poorer school performance suggests that a prudent policy would be to discourage school students from working more than a few hours per week.

CERG has gradually built up acceptance for the proposition that child labor in Britain is a worthwhile subject for research. Accordingly, funding has been made available by non-governmental organizations campaigning on child labor, local authorities, who are legally responsible for controlling child labor in Britain, research foundations and, most recently, agencies of central government in Scotland. It has become possible to widen these investigations to deal, for example, with the quality of work and the risks children face.

\section{International Perspectives}

In the mid-1990s, the work of CERG moved beyond the British Isles to take on a global 
perspective (see, for example, McKechnie \& Hobbs, 1998 and Hobbs, McKechnie, \& Lavalette, 1999). CERG became involved in the work of the International Working Group on Child Labour (IWGCL) which had been set up jointly by the International Society for the Prevention of Child Abuse and Neglect and Defence for Children International and supported financially by a wide range of other organizations. Its aim was to sponsor a number of parallel studies of countries throughout the world and produce a report in time for the meeting on Child Labor which was to be held by the International Labour Organization in 1998. CERG started by providing a report on its work to the British subcommittee of the IWGCL. It was then drawn more and more into the activities of the IWGCL, and eventually Jim McKechnie and Sandy Hobbs were invited to write the body's final report (McKechnie \& Hobbs, 1998).

The two main lessons to be drawn from the experience of working with the IWGCL are, first, that moral indignation is not enough, and, second, that the study of child labor requires more careful and precise analysis.

Involved in the IWGCL were many activists campaigning against the evils of child labor in different parts of the world. Report after report has demonstrated that the conditions under which many millions of children live and work are utterly deplorable. It is not surprising that many people involved with such matters have a strong sense of moral outrage at what they see. Unfortunately, the emotions aroused can interfere with the processes of information gathering and analysis which are necessary if progress is to be made. A specific example will illustrate the point.

During the existence of the working group, a British television company made a programme which claimed that a well-known British retailer was selling clothes labelled "Made in Britain" which were actually made in Morocco. Furthermore, it claimed that the factory at Meknes in Morocco employed large numbers of girls who were working in unacceptable conditions. The clothes company acknowledged the error in labelling but successfully demonstrated in the law courts that it was unaware of conditions in the factory at Meknes. As far as the British public were concerned, that was the end of the story. However, as an IWGCL report demonstrated, that was not the end of the story in Meknes (Zalami, Reddy, Lynch, \& Feinstein, 1998). The IWGCL's local researchers found that, because of the publicity, the factory owners had dismissed the girls. Unfortunately, for most of them this meant that they had to find other work which was in most cases both less well paid and in more degrading conditions. The television journalists had been understandably indignant by what they discovered in the Meknes factory but, by unthinkingly publicizing it without concern for the consequences of their actions, they had actually caused harm to the girls concerned.

The other lesson to be learnt, namely the need for careful and precise analysis, no doubt comes as no surprise to behavior analysts. However, it was by no means easy to persuade everyone concerned with child labor that this was the case. Eventually, the CERG members proposed what they called a Balance Model (Hobbs \& McKechnie, 1997; McKechnie \& Hobbs, 1998, Hobbs \& McKechnie, 2004) which has received fairly broad, but by no means universal, acceptance. In explaining the emergence of the Balance Model it is probably best to start with a discussion of a terminological 
distinction which we found quite widely used by writers on child employment (e.g. Fyfe, 1989; Otis, Paszor, \& McFadeen, 2001). Such writers distinguished between Child Labor and Child Work. By Child Labor they meant all of the self-evidently deplorable types and conditions of work which campaigners throughout the world sought to abolish. On the other hand, they acknowledged that some children, especially in economically advanced countries, were employed in acceptable ways in activities which might actually benefit them. This they referred to as Child Work. The main disadvantage of this distinction is that it does not deal with where exactly the line should be drawn between the good and the bad. This might not be a serious problem if the employment of children was always to be found in one or other of these easily distinguished categories. Some critics argued that this was not the case and that children's work should be thought of as falling on a continuum from very bad to very good (Feinstein, 1997; White, 1995). This was a more acceptable point of view, but is still insufficiently analytical.
The Balance Model assumes that for the child a job may have both cost and benefits. Both should be explored. The costs and benefits listed in Figure 1 are not meant to be definitive but are drawn from the existing literature on child labour. Each needs to be examined empirically. Rather than thinking of a particular job falling at some specific position on a continuum, the Balance Model allows for jobs to be regarded as having both potentially good and potentially bad features. In analysing jobs, we should look for potentially beneficial and potentially harmful features and not allow ourselves to be blinded by one outstanding feature. The journalists at Meknes reported simply the girls' bad working conditions. What they failed to note was that the girls were receiving a wage which, though small, was necessary for the household economy. Furthermore, the jobs had a degree of acceptability in their community. The journalists' actions led to most girls finding themselves in less well paid and lower status jobs. The use of the Balance Model is particularly important when planning intervention. To justify an act of intervention

\begin{tabular}{|cc|}
\hline COSTS OF WORK & BENEFITS OF WORK \\
\hline Danger to health, safety & Sense of autonomy \\
\hline Limit to free time & Sense of self-reliance \\
\hline Limit to parent/peer contact & Economic knowledge \\
\hline Negative impact of education & Business knowledge \\
\hline Encourage instrumentalism & Work experience \\
\hline Etc. & Etc. \\
\hline
\end{tabular}

Figure 1: The Balance Model. 
one must demonstrate that one is arranging contingencies, such that the alternative circumstances that the child is in subsequent to the intervention have a better balance of good and bad features than the circumstances from which the child is removed. Amongst the forms of child labor which raise the greatest degrees of indignation are children as soldiers and children as prostitutes. However, child soldiers and child prostitutes, whatever evils they face, are at least fed and clothed. Thus an acceptable intervention programme does not simply involve removing the children from the army or the brothel, it must also provide food, clothing and alternative meaningful activities.

There are various programmes which encourage consumers to purchase only goods which can be certified as not having been produced with the use of child labor. The main reason that such campaigns do not have the complete support of activists, is that they do not necessarily tell us what has happened to the child workers who were previously employed. The best justified programmes to deal with unacceptable forms of child labor are those which provide alternative sources of income for the family (since children are sometimes key contributors to the family budget) and adequate schooling or training (through which the child may hope to have better earning potential as an adult).

The final issue to mention arises from the international work concerning what is termed the "Voices of children". Many of the sociologists and social anthropologists who have contributed a large part of the research on child labor worldwide stress the need to listen to the views of children and suggest that our understanding of child labor will be crucially flawed if we do not seek to take account of children's subjective experiences of work. This approach is particularly characteristic of the group espousing what is called the New Sociology of Childhood (e.g. James, Jencks, \& Prout, 1998). It is also a common view amongst activists campaigning on behalf of child workers (e.g. Johnson, Hill, \& Ivan-Smith, 1995). Superficially at least, such a stance is not in tune with the natural science approach of behavior analysts. There is a danger that adopting the slogan "Listen to the voices of children" will lead to a naïve approach to interpreting what children say. In particular, what a child says may be treated as the expression of an inner state rather than the product of many past and current circumstances. However, given the inadequacies of much evidence collection and analysis, listening to what children say may be a useful way of ensuring that important factors are not ignored. What would have happened if the Meknes girls had been consulted about the consequences of publicizing their position?

\section{CONCLUSION}

It must be stressed that CERG is not made up of a team of behavior analysts. Although the initial impetus for its work came from behavior analysts, CERG has included amongst its personnel non-behaviorist psychologists, as well as specialists in sociology and social policy. It may be asked, therefore, whether CERG's activities have been distinctively behavior analytic in any ways and whether any of its work has been in conflict with behaviorism. The clearest influence of behaviorism on CERG may be seen in its stress on the need to painstakingly collect evidence of the nature of the phenomena being studied 
and the questioning of poorly thought out concepts. Had CERG been more behaviorist in orientation, one might have expected a greater emphasis on observation of children working (as opposed to the use of questionnaires and interviews) and a greater emphasis on the development of intervention strategies. However, the fact that observation and intervention have until recently played little part in the group's activities should not be ascribed to any departure from behaviorist principles or any hostility to behaviorist methods. In its early days, CERG had to operate with extremely limited resources and, in obtaining financial support, the group had to devise plans which were acceptable to funding bodies. Observation in the workplace is labor intensive and difficult to organize. CERG has frequently been in the position of attempting to establish the extent and character of problems associated with children's work. Only when local authorities and other sources of funding have been persuaded of the nature of the problems, are they likely to finance intervention. One of the practical aims of CERG is to develop and monitor intervention strategies aimed at increasing the benefits and reducing the costs of children's work. This will involve cooperating with politicians and officials to agree goals and to arrange changes in the contingencies under which children work.

Two final questions may be posed. First, since the empirical research carried out by CERG has been confined to Britain and Ireland, how relevant is it to the understanding of child labor worldwide? It is clear that the character of child labor varies considerably from country to country and even within countries (see Hobbs, McKechnie \& Lavalette, 1999). This makes generalization hazardous. Nevertheless, there are certain principles adopted by CERG which may be adopted usefully irrespective of the setting in which researchers work. The need for painstaking collection of information and the need for careful analysis of existing circumstances and of proposed alternatives will apply everywhere. They are implicit in the methods of natural science of which behavior analysis is a branch. In addition, it may be argued that those concerned with child labor in economically underdeveloped countries should take note of a key CERG finding, namely that most children in Britain have paid employment before they leave school. The fact that developed countries have not abolished child labor, but changed its main characteristics, may inform the strategies of those in developing economies who are trying to abolish the most unacceptable forms of work undertaken by children.

Secondly, how relevant is the experience of CERG to other attempts by behavior analysts to move into fresh areas and tackle new issues? It will be noted that the first steps taken towards this research programme were taken two decades ago. Developing a new field of research can be a slow process, particularly, as was the case with child employment in Britain, one has to establish that an area of concern does actually exist. There is a need for patience. It may be further noted that whatever CERG has achieved it has not been through the efforts of behavior analysts alone. The historical isolation of behavior analysis from the rest of psychology has been clearly demonstrated (for example, by Coleman and Mehlman, 1992). In the long run, if behavior analysis is to make its full contribution to understanding human behavior and solving human problems, should there not be moves 
to diminish that isolation? In many fields there are variations in the methods of enquiry and analysis employed. Some scholars are more scientific than others. If a scientific cultural analysis is to develop out of behavior analysis, behavior analysts interested in cultural phenomena may benefit from forming alliances with the more scientific scholars who are already working in fields so far relatively unexplored by behaviorists.

It may be that some behavior analysts might consider that the activities of CERG are too remote from the mainstream concepts and methods of their discipline. This may be so. However, if child labor is acknowledged as an important area of research, it would be helpful if any behaviorists who might be critical of CERG were to propose viable alternatives.

\section{REFERENCES}

Coleman, S. R., \& Mehlman, S. E. (1992). An empirical update (1969-1989) of D. L. Krantz's thesis that the experimental analysis of behavior is isolated. The Behavior Analyst, 15, 43-49.

Cornwell, D., Graham, K., \& Hobbs, S. (1999). Honoured in the breach: Child employment law in Britain. In M. Lavalette (Ed.) A thing of the past: Child labour in Britain in the nineteenth and twentieth centuries (pp. 216-230). Liverpool: Liverpool University Press.

Feinstein, C. (1997). Understanding the nature of child work. Paper presented at Conference on Urban Childhood, Trondheim, Norway, June 9-12.

Fyfe, A. (1989). Child labour. Cambridge: Polity Press. Greenberger, E., Steinberg, L. D., \& Ruggiero, M. (1982). A job is a job is a job... or is it? Behavioral observations in the adolescent workplace, Work and Occupation, 9, 79-96.

Hobbs, S., \& Cornwell. D. (1985). La psychologie, le loisir et le travail des enfants, in M. Romer (Ed.) Le temps libre et le loisir: Actes du Congres Mondial de Recherche de Marly-le-Roi, 24-28 September, 1984, pp III-8-9-III-8-12. Paris: Association pour le Diffusion de la Recherche sur l'Action Culturelle. Hobbs, S., \& Cornwell, D. (1986). Child labour: An underdeveloped topic in psychology, International Journal of Psychology, 21, 225-234.

Hobbs, S., \& McKechnie, J. (1997). Child employment in Britain: A social and psychological analysis. Edinburgh: Stationery Office.

Hobbs, S., \& McKechnie, J. (2004). The balance model reconsidered: Changing perceptions of child employment. Paper presented at International Symposium: What does work mean to children, Berlin Technological University.

Hobbs, S., McKechnie, J., \& Lavalette, M. (1999). Child labor: A world history companion. Santa Barbara CA: ABC-Clio.

James, A., Jenks, C., \& Prout, A. (1998). Theorizing childhood. Cambridge: Polity Press.

Johnson, V., Hill, J., \& Ivan-Smith, E. (1995). Listening to smaller voices. London: ActionAid.

Lavalette, M., McKechnie, J., \& Hobbs, S. (1991). The forgotten workforce: Scottish children at work. Glasgow: Scottish Low Pay Unit.

Lepper, M. R., \& Greene, D. (1975). Turning play into work: Effects of adult surveillance and extrinsic rewards on children's intrinsic motivation. Journal of Personality and Social Psychology, 31, 479-486.

McKechnie, J., \& Hobbs, S. (1998). Working children: Reconsidering the debates: Report of the International Working Group on Child Labour. Amsterdam: Defence for Children International.

McKechnie, J., \& Hobbs, S. (2001). Work and education: Are they compatible for children and adolescents? In P. Mizen, C. Pole, \& A.Bolton (Eds.) Hidden hands: International perspectives on children's work and labour (pp. 9-23). London: RoutledgeFalmer. 
Mizen, P., Bolton, A., \& Pole, C. (1999). School aged workers: The paid employment of children in Britain, Work, Employment and Society, 13, 423438.

Otis, J., Paszor, E. M., \& McFadeen, E. J. (2001). Child labor: A forgotten focus for child welfare, Child Welfare, 80, 611-622.

Pond, C., \& Searle, A. (1991). The hidden army: Children at work in the 1990s. London: Low Pay Unit.

Skinner, B. F. (1948). Walden Two. New York: Macmillan.

Skinner, B. F. (1976/1974). About behaviorism. New York: Vintage Books.

Steinberg, L. D., Greenberger, E., \& Ruggiero, M. (1982). Assessing job characteristics when "perceived' and "objective" measures don't converge,
Psychological Reports, 50, 771-780.

Stern, D., \& Briggs, D. (2001). Does paid employment help or hinder performance in secondary school? Insights from US high school students, Journal of Education and Work, 14, 355-372.

White, B. (1995). Globalization and the problem of child labour. Working Paper, International Working Group on Child Labour, Amsterdam.

Zalami, F. B., Reddy, N., Lynch, M. A., \& Feinstein, C. (1998). Forgotten on the Pyjama Trail. Amsterdam: International Working Group on Child Labour.

Invited paper

Received October 18, 2005 